\title{
A Study on the Female Consciousness in Hemingway's Literary Works
}

\author{
Chunmei Yu \\ Public Foreign Language Education College, Beihua University, \\ Jilin City, Jilin Province, 132013, China
}

\begin{abstract}
Hemingway is one of the most famous American writers in the twentieth Century, and as everyone knows, the code hero in his works is familiar to many people. Because he often uses fishing, hunting, boxing and bull fighting as the theme of his story, he is regarded as a male chauvinism without female consciousness. However, after a careful reading for Hemingway's works, we can see that Hemingway has created many female characteristics. Based on the author's learning and practical experience, this paper put forward three typical female consciousness in Hemingway's literary works, namely: traditional female, new female and tragic female. The female characters in Hemingway's novels have complex personality characteristics, and the women often have the fate of tragedy, which reveals Hemingway's pessimistic female consciousness.

Keyword: Female consciousness; Hemingway literary; Traditional female; New female; Tragic female
\end{abstract}

\section{Introduction}

Hemingway is a writer with a strong female consciousness, and his works are a real and vivid record for the women's mental state and living condition, which has always been ignored by the academic circles. After a comprehensive, detailed and in-depth interpretation for Hemingway's works, the author holds that Hemingway's works not only have strong female consciousness, but also create a series of strong female characters[1]. As a matter of fact, as a great and profound, Hemingway's view of women is not so shallow, and he had different occasions to 
talk about their feelings about the formation of female characters in different times. Therefore, it is necessary to be careful to observe whether Hemingway has the feminine consciousness. The text linked the writer's life thoughts and put them into the specific cultural background to research Hemingway's female consciousness.

\section{Traditional Female}

In the life of love, traditional women are loyal to love, however, all of them are often used and despised by men, as a result, they often become victims of men, living in conflict and confusion. In "A farewell to arms" and "For whom the bell tolls", the women are the representatives of outstanding women. They are traditional in their sincere kindness to life, and pay attention to giving and dedication; They have knowledge, culture and their own pursuit of career; They are loyal to their cause and loyal to love[2] The people who have read the "A farewell to arms" can not forget the love story between the hero and heroine. At first, Henry and Catherine were not very serious about their relationship and sex, and took everything as a game, but then they found that they had fallen in love, so they began to take their feelings and their love seriously. Catherine not only gave Henry love, but also taught him the meaning of true love. Catherine thought that: Loving a person is to lose yourself, and to achieve the perfect unity of spirit and body with the one their love. Catherine is pursuing the highest level of love between men and women, and her unselfish love made Henry to be someone who is loyal to love. In "For whom the bell tolls", Maria, the heroine, used a faithful love to get a new life, at the same time, she also lit the fire of the love of life. After suffering Maria met Jordan, she fall in love with him, and then their lives turned a new leaf. Maria and Catherine's view for love is same, and they all pays attention to giving and dedication, pursuits the spirit of unity between husband and wife. Maria repeatedly told Jordan that she wanted to be his wife, to make him happy, to be part of the other party. Maria's selfless love for Jordan has immeasurable significance. The happiness of love makes him feel the stagnation of time, the eternity of life and the great power of love.

\section{New Female}

The socialized production of capitalist society brings people a variety of employment opportunities, so many women could walk out of the closed family life and come out of the community to participate in the work. They have their own income, and they no longer rely on men in the economy. Women bid farewell to the traditional roles of husband and child, and they can have their own life and the pursuit of value[3]. The "Two World War" broke the naive "patriotic" enthusiasm and "world peace" dream. With the disintegration of traditional social values, women enjoy more rights and freedom, and their thoughts and actions 
become more liberating. Wearing short skirts, short hair, smoking and drinking, unmarried cohabitation ware quite common in that time. Women's personality became more complex and complicated, so they were called "new female".

The female characters described by Hemingway are often open, innovative and unconventional, and they are often referred to as "new female". The reasons they are called "new female" are that they have the courage to pursue their own ideals, abandon the traditional living habits, do not meet the false love life, bold attempt to "sexual freedom". The "new female" is the vanguard of social life, and they are hard to be accepted by the public, which determined that their life outcome are often backfired, painful and tragic. In Hemingway's short novels, Such as "Cat in the rain", "Michigan to the north", "Francis's brief happiness" and "The sun also rises", people often can see this kind of woman[4].

Belet Asley is the representative of "new female" in nineteenth Century, and she has the characteristics of ideological emancipation and sexual freedom. Asley worked as a nurse. She is a woman of culture. After losing her lover in the war, she no longer believed in traditional values and led a life of depression and indulgence. As a representative of new female, she was trying to get out of the range of activities that society expects, therefore, she deliberately broke into the scope of men's activities to attract public attention. Asley deal with a few men, tried to conquer men to meet the spiritual emptiness of the world. Her beauty is her hunting weapons, Jack, Robert, and the matador, Pedro, became her captives. Through this new female character, Hemingway reproduced the living condition of the "lost generation", clearly conveyed his sympathy for the new woman, and implied the plight and danger of the new women's betrayal of traditional ideas.

\section{Tragic Female}

Whether "new female" or "traditional female", the standards are relative. The female characters in Hemingway's novels have their own complexity in character. They are both modern and traditional, rebellious and conservative, but they all have one thing in common: they cannot escape the fate of tragedy. People often say that Hemingway's outlook on life is pessimistic, so his characters always end up in tragedy, which is not only reflected in the male characters in his novels, but also in the female characters in his novels. Looking at the female characters in Hemingway's works, no matter what kind of environment they are in, their life is tragic. In Hemingway's two major novels "Farewell to arms" and "For whom the bell tolls", they all ended with the tragedy of the main character of the story. The former heroine Catherine died of dystocia and the heroine Maria lost her lover. In addition, the tragic female characters described by Hemingway appeared in his other works[5].

In the "Cat in the rain", American wife is full of fantasy and expectation, but her husband was indifferent to her demands. For this kind of passion, the reader is very worried about the future development. The shop owner sent the cat to show his sympathy and understanding for the American wife, which brought warmth to the lonely cold rainy season. Only outsiders can understand the needs of the 
American wife, but they one who can bring a little comfort is not her husband. This marriage is unfortunate, the female characters involved in it are tragic, and the outcome is very worrying.

For Margaret in "The Short Happy Life of Francis Macomber", her love with Francis was a deal of money and beauty. What attracted Margaret was her husband's money and what attracted her husband was Margaret's beauty. Before they went hunting in africa, Francis had known his wife's conduct, but the two sides still live together because of their own needs. For her husband's cowardly behavior, Margaret can not understand and accept. She used to rely on cheating to fill the empty days, even openly contacted with other men, regardless the expense of her husband's feelings. Such a marriage is sad. Eventually, Margaret was completely out of her husband's trust and favor, and she killed her husband Francis[6]. Margaret could have left her husband in a reasonable and lawful way to pursue her hope, but instead of doing so, she turned into a Murderer. Margaret became a victim of his beauty and Francis's money. Isn't it a tragedy?

Asley, the heroine of the sun, is a young and beautiful woman. She lost her husband in the war and her son died in the accident. Since then, she lost the spiritual sustenance of life, no longer believed in traditional values, lived a lost, dissolute days. Asley is very clear that Jack loves her, but Jack's impotence is a fact that cannot be changed. Asley knows that Jack is very painful, but she had sex with other men in the face of Jack. Robert thought that she had a noble background and should have good qualities. He pursued Asley and had a sexual relationship with her. After they had a romantic day, she left Robert. After the encounter with Pedro, she was immediately captivated by the handsome young man. It was not Pedro's fighting skill, but his handsome appearance that made her fall in love with him[7]. Finally Pedro was seduced, and Asley's desire was fulfilled. Asley got to know one after another man, but it could not settle down her lonely heart. After a time of crazy sex, all the men could not satisfy her, and she eventually returned to Jack's side. Asley love Jake, but she has such damage to Jack. With Jack's sexual impotence. The trauma of the heart cast a shadow over their love, so it was decided that Asley's fate was doomed to be tragic.

\section{Conclusion}

Although Hemingway has limitations and deficiencies in shaping female characters, his efforts to portray the female characters and the distinctive sexual consciousness can not be denied. The complexity of the female characters in Hemingway's novel showed the women's confusion and hesitation in the new era, touched the basic problems of the women's world. The tragic fate of these female characters is very thought-provoking, but also reflects Hemingway's pessimistic attitude towards life. In fact, if we are based on the background of modern western civilization, we will examine the metaphor of Hemingway and his novels, and we should be seen that the decline of patriarchal culture and the awakening of female consciousness are the inevitable result of social and historical development. 


\section{References}

[1] Xiong Jie. An analysis of the female consciousness in the works of Hemingway. Chinese construction, 35, pp.30-31, 2014.

[2] Meng Hong. The embodiment of the "new women" image in Hemingway's works. Heilongjiang Social Sciences, 06, pp.107-109, 2007.

[3] Ni Qiumei. On the feminine archetype in Hemingway's works. Journal of Huainan Normal University, 04, pp.57-60, 2013.

[4] Shao Chun. Comments on female consciousness in Hemingway's works. Journal of social science of Jiamusi University, 03, pp.69-71, 2005.

[5] Tichun Peng, Fengxiang Wu. The track of female consciousness in Hemingway's works. Journal of Xichang Teachers College, 03, pp.28-32, 2002.

[6] Zheng Shan. On Hemingway's female consciousness. Journal of Chifeng University (Chinese philosophy and Social Sciences Edition), 05, 96-97, 2010.

[7] Gu Yan. Women in Hemingway's works. Journal of Hebei University (PHILOSOPHY AND SOCIAL SCIENCES EDITION), 02, PP.31-33, 1999. 